\title{
Foreign Policy in the real world: the Obama years
}

\author{
Política Externa no mundo real: os anos Obama
}

DOI: https://doi.org/10.22456/2178-8839.107689

Joseph Marques

Webster University, Geneva, Switzerland joseph.marques@webster.ch

\begin{abstract}
This review essay examines three books written by senior former Obama administration members - Susan Rice, Samantha Power, and Ben Rhodes. It highlights how the authors manage to present many of the Obama administration's internal debates, as well as reveal the limitations of its foreign policy.

RICE, Susan. Tough Love: My Story of the Things Worth Fighting For. New York: Simon \& Schuster, 2019, 544p., ISBN: 978-1-50118-997-5. POWER, Samantha. The Education of an Idealist: A Memoir. London: Dey Street Books, 2019, 592p., ISBN: 978-0-06282-069-3.

RHODES, Ben. The World as It Is: A Memoir of the Obama White House. New York: Random House, 2018, 428p. ISBN: 978-0-52550-935-6.

Keywords: Obama; American Foreign Policy; Susan Rice; Ben Rhodes; Samantha Power.

\section{Resumo}

Esta resenha apresenta a análise de três livros escritos por ex-assessores seniores do governo Obama - Susan Rice, Samantha Power e Ben Rhodes. A resenha sublinha como os autores conseguem apresentar muitos dos debates internos daquela administração, bem como revela as limitações de sua política externa.
\end{abstract}

ICE, Susan. Tough Love: My Story of the Things Worth Fighting For. New York: Simon \& Schuster, 2019, 544p., ISBN: 978-1-50118-997-5. POWER, Samantha. The Education of an Idealist: A Memoir. London: Dey Street Books, 2019, 592p., ISBN: 978-0-06282-069-3. RHODES, Ben. The World as It Is: A Memoir of the Obama White House. New York: Random House, 2018, 428p. ISBN: 978-0-52550-935-6.

Palavras-chave: Obama; Política Externa; Susan Rice; Ben Rhodes; Samantha Power. 


\section{Foreign Policy in the real world: the Obama years}

Students of American foreign policy have often complemented their review of official documents, speeches and policies with personal memoirs and books by diplomats, public officials and political appointees regarding their experience at the highest levels of U.S. foreign policy bureaucracy - the Department of State, the National Security Council (NSC) and the U.S. Mission to the United Nations (USUN). While the Secretary of State is the nominal leader of the foreign policy team, the role of National Security adviser has grown in stature as well as in intellectual heft over the last few decades. While several previous secretaries of State have left an indelible mark on U.S. foreign policy (i.e. Rusk, Kissinger, Shultz, Baker Christopher, Albright, Powell and Rice) a few national security advisers (i.e. Bundy, Kissinger, Scowcroft, Brzezinski, Lake, Rice) have also contributed important strategic thinking through their personal accounts.

The Obama administration's foreign policy alumni have now begun publishing their own memoirs of their time in the West Wing, the "situation room" (Sit Room) and at the U.S. Mission to the United Nations (USUN). These latest memoirs by three top members of Obama's foreign policy team join earlier books by Obama's two secretaries of State (Hillary Clinton 2014 and John Kerry 2018). All three authors have worked on the National Security Council as well as at the White House and the State department.

Ben Rhodes served as the deputy director of White House speechwriting and senior director for speechwriting at the NSC. The youngest of the three authors, Rhodes arrived in Washington with no particular foreign policy specialization. His role underscores the enormous importance of communication skills in today's political environment regarding domestic and foreign policy. According to Rhodes, Obama acknowledged the need to control the narrative through storytelling and speeches to promote his administration's values. Rhodes' job included writing most major speeches for the President (together with Jon Favreau and team) and to coordinate the spokespeople for State, Defense, and other agencies. Rhodes examines Obama's foreign policy challenges from the perspective of a speechwriter focused on crafting a cohesive narrative highlighting Obama's principles and values. Among his most important speeches were the "Cairo" speech early in Obama's first term as well as Obama's Nobel Peace Prize acceptance speech. His account is an unusually frank description of the daily grind of working in Washington under a constant barrage of foreign policy challenges. Rhodes contrasts many high profile events around the world involving global leaders with less glamorous aspects behind the scenes (the constant lack of sleep, innumerable Chinese take-out dinners, lost hours going to and from airports as well as precious friendships forged from working long days under constant pressure and the occasional stress -busting party where Rhodes often ruled the dance floor - including personal reminiscences of up-close meetings with world leaders, celebrities and their immediate staff (the Queen of England, Angela Merkel, David Cameron, etc.).

Samantha Power started working with Obama at age 34 (Rhodes at 29 and Rice started at the NSC at 28). Following a career as a journalist, human rights activist, academic at Harvard and helping out with the Obama campaign, Power became the Senior Director and Special Assistant to the President for Multilateral Affairs at the NSC. Power previously covered the Balkan war as a journalist and was awarded the Pulitzer prize for her book "A Problem from Hell: America and the Age of Genocide". The first half of the book describes her evolution from an outsider to an insider and comparing "upstanders" (those that stand up to genocide) and "bystanders" (those who do nothing or little). As a government official, Power was constantly confronted with the challenge of how to change events rather than merely describe them as she did as a journalist. Notwithstanding Power's academic credentials and experience with Washington's foreign policy bureaucracy, she shares her surprise of discovering, upon her arrival at the White House, that there is no “operating manual”, and that she would have to learn on the job. Power provides several humorous accounts regarding her first days at the White House (getting lost on the way to her first Oval Office meeting and her confusion with so many similar-sounding titles of White House staff ("assistant”, “deputy assistant”, and "special assistant” to the President, etc.).

Power shares advice offered by Rice - "Who will report to You? What will You be responsible for? If you are responsible for nothing, nobody will call you” (POWER, 2019, p. 205). Personalities and egos often clash between personal 
values and political expediency. Though all three authors worked closely together each author draws different lessons from and holds different opinions of certain events and people: Power describes Richard Holbrooke - a major figure in democratic administrations since the Vietnam War - as an important mentor while Rice recounts the bitter animosity between the two; Rhodes ponders why Holbrooke was never able to become close to Obama and miss the chance of becoming Secretary of State. Power confesses her reluctance to speak up on human rights when faced with the overwhelming "realist" culture of the West Wing which “downplayed the importance of values” (POWER, 2019, p. 220). She recalls additional advice from Rice to "act like you are the boss" (POWER, 2019, p. 220). Getting into the room is, apparently, only the first battle in Washington.

Unlike Rhodes and Power, Rice arrived at the NSC with a traditional foreign policy background (Ph.D. in International Relations from Oxford, family connections to Madeleine Albright, and deep knowledge of Africa, etc.) She quickly became the youngest ever regional assistant secretary of state for African affairs and led U.S. policy for all forty eight countries of Sub - Saharan Africa. Her experience is also the broadest having spent time at all three centers of foreign policy decision-making: NSC, USUN and Department of State. Both Rice and Power describe the challenge of promoting U.S. foreign policy priorities at USUN - a job with huge potential and visibility and even greater potential for disappointment. While democratic administrations normally treat the USUN position as a cabinet-level job, several Republican administrations have required the U.N. ambassador to report to the secretary of state through the assistant secretary of state for international organization affairs. Rice recalls how the USUN in New York is very different than Washington-based jobs, much more "outward - facing" - representing the U.S. to the world while the NSC role is primarily an "inward - facing" job — advising and supporting the president, formulating and coordinating policy among the agency heads, guiding strategy, and managing the NSC staff (RICE, 2019, p. 346).

All three memoirs underscore the dilemma between strategic principles and personal values, hard power and the limitations of intervention, how the world ought to be and how it really is. Rice and Power make a particularly important contribution by relating their experience and challenges working as women (and mothers) in national security and as part of Obama's all female national security team. Though President Reagan's first UN ambassador, Jeanne Kirkpatrick, was the first woman to hold a national security cabinet position and Madeleine Albright served as President Clinton's UN ambassador and first female Secretary of State neither had to deal with raising young children (or IVF appointments) during their mandates.

All three books offer an insider's view of the NSC, Department of State and USUN - incessant meetings of "principals" and "deputies", the constant back and forth between the office and the "Sit" Room and the bureaucratic "process" with its paper trail of briefing memos, information memos and decision memos. All three texts contribute to our understanding of the major foreign policy issues of the time, Obama's decision-making process and the role of countless actors in the foreign policy circle. Rhodes and Power offer earnest personal reflections of the frustration resulting from the inevitable conflict between personal values and the broader political considerations of a large number of players with competing interests. Rice focuses primarily on the policy process and the constant challenge to stay on top of an unrelenting flow of unexpected events and demands.

Obama comes across as a cerebral figure, a serious listener and analytical thinker but no clear Obama foreign policy emerges from these memoirs. Obama appears ambiguous regarding the ultimate effectiveness of the U.N. and the Obama doctrine can be summarized as to avoid doing "stupid shit". There is, however, a general consensus that Syria was Obama's most difficult foreign policy decision. Syria was also Rice's most painful experience when she was severely criticized by the Republican opposition following the Benghazi crisis during which the U.S. Consulate was raided, killing four U.S. personnel including Ambassador Chris Stevens.

Each book covers the major foreign policy issues of the Obama period (i.e., ISIS, North Korea, Afghanistan, Iraq, Syria, Libya, Ebola, etc.) from three different perspectives and each author dedicates special attention to a handful of issues 
of personal interest: Rhodes regarding Laos and Cuba, Power on Myanmar and her relationship with Russian ambassador Vitaly Churkin and Rice on Nigeria and Kenya.

These memoirs should become required reading for students of U.S. foreign policy. These are important younger voices and include a long missing female perspective on national security. In addition to personal insights regarding the major foreign policy issues of the Obama era there is much for students to learn about how Washington and its foreign policy establishment actually function.

These books highlight several important political realities: 1 ) every agency of the government has its own interests which usually outlast any presidency; 2) people join government only to find that there is no "operating manual” and, irrespective of their background, face a steep learning curve; 3 ) institutions are made up of people who have values which lead, ultimately, to specific choices. Together, these three books capture many of the internal debates inside the Obama administration and reveal the limitations of a foreign policy motivated by the principle of humanitarian intervention.

Despite attention to countries such as Iran, Syria, Somalia, Rwanda and Cuba there is precious little else on the Global South. Rice (2019, p.358) describes the time when Pres. Dilma Rousseff of Brazil berates Obama for an eavesdropping scandal while attending the 2013 G20 Summit in St. Petersburg. It is clear that the bigger issues of U.S. foreign policy during the Obama years left very little precious time and energy to focus on the rest of the world.

These three books serve as excellent sources to understand how U.S. foreign policy is conducted and help explain U.S. decision-making in the Obama era. Equally important to anyone considering a career in government are the candid descriptions of the challenges of these jobs, the steepness of the learning curve, the long list of necessary critical skills, the required patience and sheer physical stamina, as well as the role of mentors and the incredibly long hours required to survive and excel in these positions. These memoirs describe what it takes to get "in the room" and once there, how to promote one's views of what seems most expedient, just and necessary, only to discover that it doesn't always end as one expects.

\section{References}

RICE, Susan. Tough Love: My Story of the Things Worth Fighting For. New York: Simon \& Schuster, 2019, 544p., ISBN: 978-1-50118997-5.

POWER, Samantha. The Education of an Idealist: A Memoir. London: Dey Street Books, 2019, 592p., ISBN: 978-0-06282-069-3. RHODES, Ben. The World as It Is: A Memoir of the Obama White House. New York: Random House, 2018, 428p. ISBN: 978-052550-935-6.

Authors' Contributor Roles 